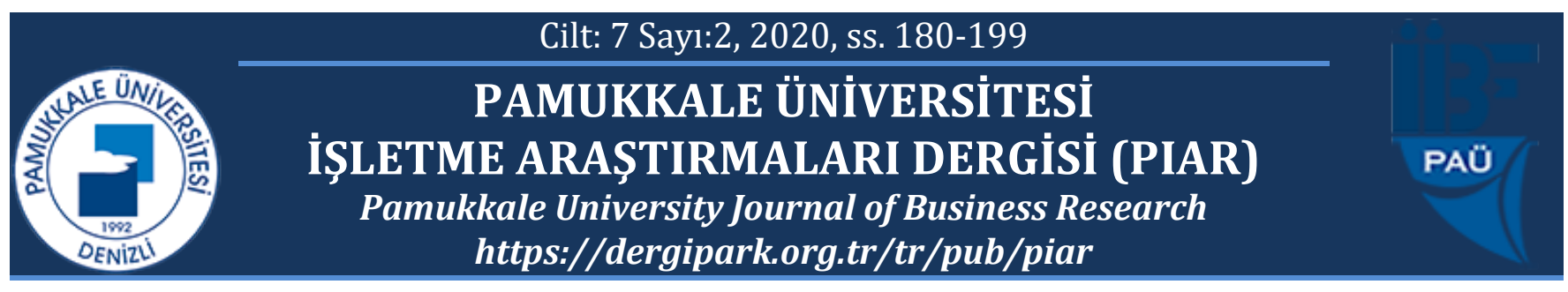

\title{
Dijital Okuryazarlık İnternet Girişimciliği Niyeti İlişkisi Üzerine Ampirik Bir Çalışma
}

\section{An Empirical Study on the Relationship between Digital Literacy and Internet Entrepreneurship Intention}

\section{Vural ÇAĞLIYAN ${ }^{*}$}

\section{Burcu DOĞANALP²}

${ }^{1}$ Selçuk Üniversitesi, İ̈BF, vcagliyan@selcuk.edu.tr, https://orcid.org/0000-0002-7964-8840

${ }^{2}$ Selçuk Üniversitesi, İ̈BF, vcagliyan@selcuk.edu.tr, https://orcid.org/0000-0002-8355-1320

* Yazışılan Yazar/Corresponding author

Makale Geliş/Received: 07.10.2020

\section{Öz}

Girişimcilik bir ülkenin ekonomik kalkınmasında önemli bir yere sahiptir. Potansiyel girişimciler olarak kabul edilen üniversite öğrencilerinin ilerideki kariyerlerinde girişimci olma davranışlarının öncülü olan girişimcilik niyetlerini değerlendirmek bu bağlamda önemli görülmektedir. Özellikle şu an öğrenimine devam eden üniversite öğrencilerinin $Y, M$ ve $Z$ kuşaklarının bireylerinin teknoloji ile birlikte anlmasi internet girişimciliği kavramının bu kuşak bireylerinden bağımsız düşünülemeyeceğini ortaya çıkarmaktadır. Internet girişimciliğinde ise dijital okuryazarlı önemli ve gerekli bir yetkinlik olarak değerlendirilmektedir. Bu bağlamda, bu çalışmada Selçuk Üniversitesi İktisadi ve Idari Bilimler Fakültesi'nde öğrenim görmekte olan öğrencilerin dijital okuryazarlıklarımı internet girişimciliği niyetleri üzerindeki etkisi değerlendirilmiştir. Yapılan alan araştırması sonucunda dijital okuryazarlığın öğrencilerin internet üzerinden girişimcilik niyetleri üzerinde olumlu etkisi olduğunu göstermiştir.

Anahtar kelimeler: Dijital okuryazarlı, internet girişimciliğ i, internet girişimciliğ $i$ niyeti

JEL kodları: M2
Makale Kabul/Accepted: 24.11.2020

\begin{abstract}
Entrepreneurship has an important place in the economic development of a country. In this context, it is important to evaluate the entrepreneurial intention of university students (considered as potential entrepreneurs) which is the antecedent of entrepreneurial behaviors in their future careers. Especially, the fact that university students who are currently studying are mentioned with technology as individuals of $Y, M$ and $Z$ generations reveals that the concept of internet entrepreneurship cannot be considered independently from the individuals of this generation. And in internet entrepreneurship, digital literacy is considered as an important and necessary competence. In this context, in this study, the effect of the digital literacy of the students studying at the Faculty of Economics and Administrative Sciences of Selcuk University on their internet entrepreneurship intentions was evaluated. As a result of the field research, it has shown that digital literacy has a positive effect on students' internet entrepreneurship intentions.
\end{abstract}

Keywords: Digital literacy, internet entrepreneurship, internet entrepreneurship intention

JEL codes: M2 


\section{GİRIŞ}

Günümüzde bilgi teknolojilerinin artan önemi beraberinde bilgi transferinin mekândan ve zamandan bağımsız yapılabilmesine olanak tanımış ve iş yapma şeklini değiştirmiştir. Pazarlanan ürünlerin satışı kolaylaşmış; reklam, marka konumlandırma, ürün tanıtımı, satış öncesi ve satış sonrası destek ve benzeri kanallar elektronik ortamda daha etkili hale gelmiştir. İnternet ve e-ticaret sadece iş örgütlerine değil; aynı zamanda bir girişimciler için de fırsatlar yaratmıştır (Bahcecik vd., 2019: 513-514; Yıldırım ve Başer, 2016: 173). Bu bağlamda internet, teknolojiyi kullanma becerisi ve uzmanlığına sahip bireylerin girişimci profesyoneller haline gelebilmeleri için zemin hazırlamış (Karabacak ve Genç, 2019: 869) ve internet girişimciliğinin ortaya çıkmasını beraberinde getirmiştir.

Girişimcilik bir ülkenin rekabetçiliğinde ve ekonomik büyüme ve gelişiminde önemli bir kaynak olarak görülmektedir (Millman vd., 2010: 570). Girişimcilik davranışını belirleyen niyeti araştırmak bu açıdan önem arz etmektedir. Giri`şimcilik niyetinin oluştuğu ve girişimcilik alanında alınan eğitimle artabileceği düşünüldügünde özellikle İktisadi ve İdari Bilimler Fakültesi öğrencilerinin girişimcilik konusunda yapılan araştırmalar için temel bir başvuru kaynağı olacağ 1 ifade edilebilir. Buna ek olarak, bilgi ve teknoloji çağı'nda doğmuş olan bir neslin girişimciliği söz konusuysa bunun internet girişimciliğiyle beraber düşünülmesi yadsınamaz. Mevcut öğrencilerin bulunduğu nesil, dijital teknoloji ile büyüyen ve teknolojiye meraklı bireyleri temsil etmektedir (Milton ve Vozzo, 2013: 74). Teknoloji yeteneği ve merakı internet girişimcisinde geleneksel girişimciden çok daha ön plana çıkan bir özellik olarak belirtilebilir (Miynat ve Özcan, 2016: 507-509; Bayrakdaroglu ve Bayrakdaroglu, 2017: 28; Chen, 2013: 233; Chen, 2014: 3). Bu bağlamda; bu teknolojiye dayalı yetenek ve merakın internet girişimciliği davranışı ve niyetini etkileyebileceği söylenebilir (Chen, 2014: 3). Başka bir deyişle, bireyin siber dünya üzerindeki kontrolü ile ilgili öz algısı, internet girişimciliği niyetini artırabilir. $\mathrm{Bu}$ alg1 dijital okuryazarlık olarak nitelendirilmektedir (Bayrakdaroglu ve Bayrakdaroglu, 2017: 28).

Bu noktadan hareketle, bu çalışmada Selçuk Üniversitesi İktisadi ve İdari Bilimler Fakültesi'nde öğrenim görmekte olan öğrencilerin dijital okuryazarlıklarının internet girişimciliği niyetleri üzerindeki etkisi değerlendirilmiştir.

\section{LITERATÜR İNCELEMESI}

\subsection{Dijital Okuryazarlık}

"Okuryazar" kavramı okuma yazmayı bilen kişileri ifade etmektedir. Okuryazar olma, toplumda "bilgili olma" olarak algılanmaktadır (Karabacak ve Sezgin, 2019: 321). Bu noktada okuryazarlık, okuma ve yazma yeteneği olarak tanımlanmaktadır (Lankshear ve Knobel, 2015: 9). Okuryazarlık ömür boyu devam eden bir edim olarak görülmekte; bu bağlamda güncel bilginin elde edilmesini içermektedir (Karabacak ve Sezgin, 2019: 321). Bunlara ek olarak; okuryazarlıkta sahip olunan bilgi kümesiyle yeni elde edilen bilginin etkileşime geçirilerek yeni çıkarımlarda bulunabilme de yer almaktadır (Dönmez, 2019: 5).

Literatürde okuryazarlığın birçok türünden bahsedilmektedir. Okuma ve yazma sözcüklerinin bileşiminden meydan gelen okuryazar kavramı aslında hangi alanda kullanılıyorsa kullanılsın o alanda bilgili olmaya işaret eder (Kurt vd., 2013: 2). Dijital çağda dijital teknolojilerin hızlı gelişimi bireyleri dijital ortamlarda icraat ve problem çözümü için 
ihtiyaç duydukları teknik, bilişsel ve sosyolojik becerilerden yararlanmalarını gerektiren durumlarla karşı karşıya bırakmıştır (Eshet-Alkalai ve Amichai-Hamburger, 2004: 421). Bu bağlamda; teknolojik ilerleme beraberinde okuryazarlık kavramının dijital okuryazarlık olarak farklı bir bağlamda ele alınmasını getirmiştir (Kabakçı-Yurdakul vd., 2013: 889). İlk kez Paul Gilster tarafından 1997 yılında “Dijital Okuryazarlık" adını taşıyan kitabında kullanılan (Bawden, 2008: 18), bazen e-okuryazarlık olarak da adlandırılan yeni okuryazarlık terimlerinden biri olarak dijital okuryazarlık, dijital ortamdan gelen yeni verilerin değerlendirilmesi ve uygulanması ve yeni bilgi ve görsellerin üretilmesi için dijital düzenleme yoluyla medyanın okunması ve yorumlanması yeteneği olarak tanımlanmaktadır (Bayrakdaroglu ve Bayrakdaroglu, 2017: 29; Coşkun vd., 2013: 1262). Dijital çağda hayatta kalma becerisi olarak da betimlenen dijital okuryazarlık, dijital ortamlardaki kullanıcılar tarafindan kullanılan bir beceri ve stratejiler sistemini belirtmektedir (Eshet-Alkalai, 2004: 102). Dijital okuryazarlık, "dijital araçları dijital kaynakları fark etmek, erişmek, yönetmek, değerlendirmek, analiz etmek ve sentezlemek; yeni bilgi oluşturmak, kitle iletişim araçlarında ifadeler oluşturmak ve başkalarıyla iletişim kurabilmek için bireylerin farkındalığı, tutumu ve yeteneği" olarak ifade edilmektedir (Duran ve Özen, 2018: 33; Demir ve Odabaşı, 2016: 374; Sakallı, 2015: 70). Dijital okuryazarlık "bireylerin çeşitli amaçlarla dijital araçlardan (bilgisayar, televizyon, cep telefonu vb.) okuyup yazma durumları"dır (Sarıkaya, 2019: 1098; Maden vd., 2018: 686; Yaman, 2019: 21). Dijital okuryazarlık, farklı teknolojik kaynaklardan doğru bilgiye erişim, yeni bilgiyi oluşturma ve meydana getirilen bilgiyi paylaşmayı kapsamaktadır (Yaşar, 2019: 21; Hamutoğlu vd., 2019: 96; Meyers vd., 2013: 358). Doğru bilgiye erişim açısından dijital okuryazarlıkta gereksinim duyulan bilginin bilgi kirliliğiyle mücadele etme yeteneğine sahip olunarak hangi kaynaktan temin edileceğini bilme ve bilgi yığını içerisinden güncel, geçerli ve güvenilir bilgiyi seçme ön plana çıkmaktadır (Ocak ve Karakuş, 2019: 1429).

Dijital okuryazarlık genellikle, teknik-prosedürel, bilişsel ve duygusal-sosyal becerilerin bir kombinasyonu olarak düşünülmektedir (Üstündağ vd., 2017: 21; Nawaz ve Kundi, 2010: 20). Dijital okuryazarlık, Ng (2012: 1067-1068) tarafından da bu üç boyutu kapsar şekilde incelenmiştir. Teknik boyut, öğrenme ve günlük aktiviteler için bilgisayar iletişim teknolojilerini kullanmada teknik ve operasyonel becerilere sahip olmayı temsil eder. Bilişsel boyut dijital bilginin ele alındığı araştırma, değerlendirme ve oluşturma döngüsünde eleştirel düşünebilme yeteneğini ifade eder. Dijital okuryazarlığın bu boyutu, bireyin etik, ahlaki ve hukuki konular hakkında bilgi sahibi olmasını gerektirir. Sosyal-duygusal boyut ise iletişim kurma, sosyalleşme ve öğrenme sürecinde interneti sorumlu bir şekilde kullanabilmeyi ifade eder. Bu boyut kişisel bilginin güvenliğini ve gizliliğini sağlamayı içerir.

Ng'ye (2012: 1068) göre dijital okuryazar olmak teknik, bilişsel ve sosyal-duygusal olan bir dizi temel becerinin geliştirilmesini gerektirir. Dijital okuryazar bir kişinin gösterebilmesi gereken temel beceriler:

- Günlük kullanım için temel bilgisayar tabanlı işlemleri gerçekleştirmek ve bilgiye erişmek

- Araştırma ve içerik öğrenme amacıyla bilgileri etkin bir şekilde araştırmak, tanımlamak ve değerlendirmek 
- Görevleri tamamlamak, sorunları çözmek veya yeni anlayışları en iyi gösteren ürünler oluşturmak için en uygun teknolojik araçların veya özelliklerin kullanımında yetkinlik seçmek ve geliştirmek

- Çevrimiçi topluluklarda uygun davranmak ve kendini dijital olarak gelişmiş ortamlarda zarar görmekten korumak.

Dijital okuryazarlıkla ilgili literatürde yer alan çalışmalardan bazıları şöyledir: Ng (2012) çalışmasında lisans öğrencilerinin dijital okuryazarlık düzeylerini araştırmıştır ve bu çalışmada da kullanılan 17 maddeden oluşan Dijital Okuryazarlık Ölçeğini geliştirmiştir. Ölçekte dijital okuryazarlık tutum, teknik, bilişsel ve sosyal-duygusal olmak üzere dört boyuta sahip bir yapıda ele alınmıştır. Maxwell ve Maxwell (2014) lisans öğrencilerinin dijital okuryazarlık düzeylerindeki cinsiyet farklılıklarını çalışmıştır. Hamutoğlu ve arkadaşları (2017), Ng (2012) tarafından geliştirilen ölçeği Türkçe'ye uyarlamışlardır. Üstündağ ve arkadaşları (2017), Ng (2012) tarafından geliştirilmiş olan dijital okuryazarlık ölçeğinin Türkçeye uyarlanmasını yapmış ve fen bilgisi öğretmen adaylarının dijital okuryazarlık yeterliklerini araştırmıştır. Göldağ ve Kanat (2018) çalışmalarında, güzel sanatlar eğitimi alan öğrencilerin dijital okuryazarlık durumlarını incelemiştir. Techataweewan ve Prasertsin (2018), karma yöntem araştırması ile Taylandlı lisans öğrencileri için dijital okuryazarlık göstergeleri oluşturmuştur. Yılmaz ve arkadaşları (2019) ise sağlık bilimleri fakültesi öğrencilerinin dijital okuryazarlık düzeylerini incelemişlerdir ve çalışmalarında öğrencilerin dijital okuryazarlık seviyelerinin orta düzeyde olduğu $(3,60)$ ve geliştirilmesi gerektiğini ve yaş, bilgisayar kullanma sıklığı, eğitim alınan bölüm, bilgisayar kullanım yılı ve bilgisayar kullanım becerisi değişkenlerinin dijital okuryazarlık becerisini etkilediğini; cinsiyet ve mobil internet sahipliği değişkenlerinin ise etkilemediğini bulgulamışlardır. Yaman (2019), sosyal bilgiler öğretmen adaylarının dijital okuryazarlık düzeylerini çeşitli değişkenler açısından ele almıştır. Hamutoğlu ve arkadaşları (2019) Bilgisayar ve Öğretim Teknolojileri Eğitimi Bölümü'nde öğrenim gören öğretmen adaylarının e-öğrenmeye yönelik tutumları ile dijital okuryazarlık becerileri arasındaki ilişkiyi araştırmıştır. Bu çalışma Doğrulayıcı Faktör Analizi ve Yapısal Eşitlik Modeli kullanarak gerçekleştirilmiş olup literatürdeki diğer "dijital okuryazarlı̆̆ın internet girişimciliği niyeti üzerinde etkisini” ele alan çalışmalardan ayrıldığı ifade edilebilir.

\subsection{Internet Girişimciliği Niyeti}

Dijitalleşme iş yapma şeklinde ve girişimcilikte bir dönüşüm meydana getirmiştir (Stalkina ve Steiner, 2020: 2765). İş yapma şeklinin giderek küçülmesi ve ağlar üzerinden yapılabilmesi girişimci bireylere de fırsat sağlayarak yeni kapılar açmıştır (Erdoğan vd., 2006: 418). İnternet girişimcilere hem küresel arenada geniş bir müşteri kitlesine erişim hem de yapılan işin maliyetlerini oldukça büyük miktarda düşürme imkânı sağlamaktadır. Ayrıca iş yapmak için ihtiyaç duyduğu sermaye miktarının az olması da girişimcinin önemli bir kazanımıdır (Erdoğan vd., 2006: 419, 425; Akbaş, 2013: 6).

Girişimci, risk üstlenerek kâr amacı güden bir işi yapan ve yöneten kişidir (Chen, 2013: 233). Girişimcilik ise, yeni fikirlerin oluşmasını, bu fikrin uygulamaya dönüştürülerek ürün ya da hizmet halini almasını ve ortaya çıkan ürün ya da hizmetin pazara sunulmasını içermektedir (Öz vd., 2019: 1059). 21. yüzyılın girişimciliği olarak tanımlanan internet girişimciliği, finansal bir beklenti ile sanal platformda bir proje üretme ve bu projeyi internet üzerinden 
müşterilere sunmak eylemidir (Karabacak ve Genç, 2019: 871; Yelkikalan vd., 2010: 496-497; Bayrakdaroglu ve Bayrakdaroglu, 2017: 28). Diğer bir ifadeyle internet girişimciliği internetten faydalanarak potansiyel alıcıların internet kanalıyla erişebilecekleri ürün ya da hizmetleri ortaya koymayı, pazarlamayı ve satışını yapmayı içeren girişimcilik faaliyetidir (Vural ve Çavuş, 2017: 51). Literatürde e-girişimcilik, dijital girişimcilik, elektronik girişimcilik, web girişimciliği (Guthrie, 2014: 116), bilişim girişimciliği, bilişim teknolojileri girişimciliği olarak da adlandırılmaktadır. İnternet girişimciliği; "risk alarak yaratıcı veya yenilikçi çözümler geliştiren ve bunları iyi yönetimle birleştiren, yeni ya da mevcut kuruluşların asıl iş alanları dışında, internetsiz var olamayacak şekillerde ekonomik aktivite veya sosyal fayda yaratmak" olarak açıklanmaktadır (Akış, 2017: 43; Gökgül, 2014: 13). İnternet girişimciliği internet altyapısıyla gerçekleştirilen bir girişimcilik alt kategorisidir (Özbek vd., 2018: 11). Ayrıca yapılan işin internet girişimciliği olarak nitelendirilmesinde işi yapanın yeni bir organizasyon oluşturmuş olması belirleyici unsur olarak kabul edilmektedir. Yine, internet kanalıyla gerçekleştirilen iş, mevcut bir organizasyon tarafından ortaya konmuş olsa dahi iş örgütünün temel iş faaliyetinin haricinde bir alanda yapılmışsa internet girişimi olarak kabul edilir (Miynat ve Özcan, 2016: 509; Gökgül, 2014: 13).

Niyet, bireylerin bilinçli planlar ve kararlar üzerinden hareket etmek için çaba sarf etmesinde sahip olduğu motivasyonu temsil etmektedir (Hejazinia, 2015: 247). Girişimcilik niyeti ise, genellikle gelişen uzun sürede gelişen girişim yaratma sürecinin ilk adımıdır; bu noktada da yeni bir girişimde bulunmada önemli bir rol oynar ve girişimci davranışlar sergilemek için gerekli bir öncüldür (Liñán ve Chen, 2009: 595). Girişimcilik niyeti; bireyin girişimcilik isteği, girişimin olabilirliği ile ilgili algısı ve bununla bağlantılı fırsattan faydalanma meylinden ortaya çıkmaktadır (Kuvat, 2019: 297).

Literatür incelendiğinde internet girişimciliği niyeti ile ilgili yapılan çalışmalar ise şöyledir: Millman ve arkadaşları (2010), Çinli öğrencilerin internet girişimciliği niyetleri ile ilgili algı ve tutumlarını motive eden faktörleri inceledikleri çalışmalarında; cinsiyet, aile geliri ve öğrenci statüsü gibi demografik faktörlerin internet girişimciliği niyeti ile pozitif yönde ilişkili olduğunu ve öğrencinin iletişim ve bilgi teknolojisi öğretilen bölümlerde okumasının ve çevrimiçi alışveriş deneyimlerinin de internet girişimciliği niyeti üzerinde önemli etkisi olduğunu bulgulamışlardır. Yelkikalan vd. (2010) çalışmalarında internet girişimcisinin karakteristik özelliklerini belirleyerek $\mathrm{Y}, \mathrm{M}$ ve $\mathrm{Z}$ kuşaklarından hangilerinin internet girişimcisi profiline uyduğunu belirlemeye çalışmıştır. Chen (2013) üniversite öğrencilerinin bilişim teknolojileri girişimciliği niyetini ve öncüllerini ampirik olarak araştırmıştır. İnternet girişimciliği niyetinin araştırıldığı çalışmasında Chen (2014), bilgi teknolojilerindeki bireysel yenilikçiliğin internet girişimciliği niyeti üzerinde doğrudan, bilgisayar öz-yeterliliğinin ise dolaylı bir etkisi olduğu sonucuna erişmiştir. Lin (2015) çalışmasında, Çin'deki üniversite öğrencilerinin internet girişimciliği niyetini demografik faktörler açısından incelemiştir. 601 öğrenci ile gerçekleştirdiği uygulama sonucunda cinsiyet, bölüm ve yılın internet girişimciliği niyeti üzerinde önemli bir etkisi olduğu sonucuna ulaşmıştır. Wang ve Lin (2016) işletme bölümü öğrencilerinde internet girişimciliği niyetini etkileyen faktörleri incelemiştir. İnce ve Altın (2018), Y ve M kuşaklarının internet girişimciliği niyetlerinin düzeyini belirlemeye çalışmışlardır. Literatürde her iki kavramı bir arada inceleyen Bayrakdaroglu ve Bayrakdaroglu (2017)'nun finansal okuryazarlık ve dijital okuryazarlığın internet girişimciliği üzerindeki etkisini belirlemek amacıyla gerçekleştirdikleri çalışmaları; 
düşük finansal ve dijital okuryazarlık düzeyindeki öğrenci grubunun ve yüksek finansal ve dijital okuryazarlık düzeyindeki grubuyla internet girişimciliği niyeti açısından karşılaştırılmasına dayanmaktadır.

\section{METODOLOJi}

Bu bölümde araştırmanın yöntemi, örneklemi, hipotezleri ve modeli hakkında bilgilere yer verilmiştir.

\subsection{Araştırmanın Yöntemi ve Örneklem}

Araştırmanın temel amacı; üniversite öğrencilerinin dijital okuryazarlıkları ile internet girişimciliği niyetleri arasındaki ilişkinin irdelenmesidir. Bu amaçla üniversite öğrencileri üzerinde anket yöntemi kullanılarak bir alan araştırması yürütülmüştür. Araştırmanın ana kütlesini Selçuk Üniversitesi İktisadi ve İdari Bilimler Fakültesi öğrencileri oluşturmaktadır. 2019 yılı için fakültede kayıtlı öğrenci sayısı 4950'dir.

Anketlerin ana kütlenin tamamına uygulanmasının zorlukları dikkate alınarak ana kütleyi temsil yeteneği olan bir örneklem grubu belirlenmiştir. Örneklem grubu belirlenirken kolayda örnekleme yöntemi kullanılmıştır. Kolayda örnekleme; belirlenen ana kütle içerisinden örneklem grubunun araştırmayı yapan kişinin kararları ile belirlenmesini esas alan kolay, maliyeti az ve hızlı olması gibi avantajlar sunan bir örnekleme yöntemidir (Malhotra, 2004: 321). Anket formları öğrencilerle yüz yüze görüşmeler yapılarak uygulanmıştır. Uygulama süreci sonunda değerlendirmeye uygun 500 adet anket formu elde edilmiştir. Ana kütleden ne kadar örnekleme ulaşılması gerektiği belirlenirken bu konuda Yazıcıoğlu ve Erdoğan (2004) tarafından hazırlanan örneklem tablosu dikkate alınmıştır. Bu bağlamda 5000 kişiden oluşan bir ana kütle için $\pm 0,05$ örnekleme hatası, $p=0,05$ (ana kütledeki her bir deneğin gözlenme ihtimali) ve q=0,05 (ana kütledeki her bir deneğin gözlenmeme ihtimali) olmak üzere belirlenen örneklem sayısı en az 357'dir. Dolayısıyla çalışmada elde edilen 500 anket formunun ana kütleyi temsil ettiği söylenebilir.

Araştırmanın amacina uygun olarak oluşturulan anket formunun ilk bölümünde katılımcıların demografik bilgilerini belirlemeye yönelik sorulara yer verilmiştir. Anketin ikinci bölümünde dijital okuryazarlık ve internet girişimciliği niyeti değişkenlerine ilişkin sorular bulunmaktadır. Öğrencilerin dijital okuryazarlık düzeylerini belirlemek amacıyla Ng (2012) tarafından geliştirilen ve Türkçeye Hamutoğlu vd. (2017) tarafından çevrilen, geçerliliği ve güvenilirliği başka çalışmalarda da test edilmiş (Göldağ ve Kanat 2018, Yılmaz vd. 2019, Yaman 2019, Hamutoğlu vd. 2019) 17 maddelik ölçekten yararlanılmıştır. Öğrencilerin internet girişimcilik niyetini ölçmek amaciyla Wang ve Lin'in (2016) çalışmalarında kullandıkları, geçerliliği ve güvenilirliği Bayrakdaroglu ve Bayrakdaroglu (2017) tarafından test edilmiş olan 3 maddelik ölçekten yararlanılmıştır. Ölçeklerin değerlendirilmesinde 5'li Likert derecelendirmesi kullanılmış olup 1 "Kesinlikle Katılmıyorum" ve 5 "Kesinlikle Katılıyorum" anlamindadır.

\subsection{Araştırmanın Modeli ve Hipotezleri}

Bu çalışmanın metodolojisi "Dijital okuryazarlığın internet girişimciliği niyeti üzerinde etkisi var mıdır?" araştırma sorusu çerçevesinde oluşturulmuştur. Bu bağlamda çalışmanın amacı, üniversite öğrencilerinin dijital okuryazarlıkları ile internet girişimciliği niyetleri arasındaki ilişkinin irdelenmesidir. Dolayısıyla, çalışmanın bağımsız değişkeni internet girişimciliği 
niyeti iken dijital okuryazarlık bağımlı değişkeni oluşturmaktadır. Dijital okuryazarlığı yüksek olan öğrencilerin internet girişimcilik niyetinin de yüksek olması beklenmektedir. Bu nedenle, dijital okuryazarlığın öğrencilerin internet girişimciliği niyetleri üzerinde yorumlayıcı etkiye sahip olduğu söylenebilir.

Üniversite öğrencilerinin dijital okuryazarlıkları ile internet girişimciliği niyetleri arasındaki ilişkiyi irdelemek amacıyla oluşturulan kavramsal model Şekil 1'de yer almaktadır.

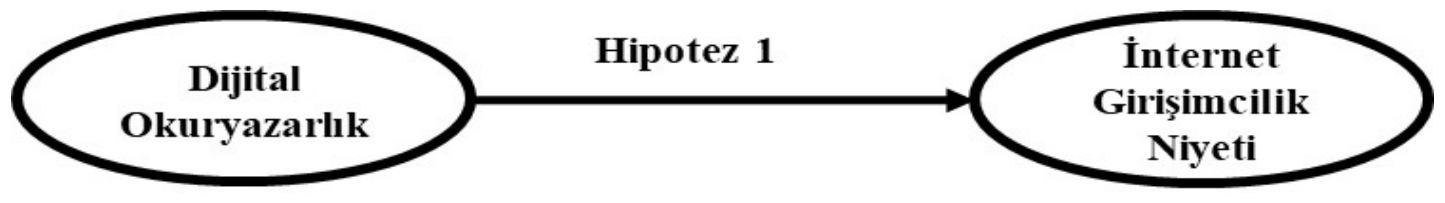

Şekil 1. Araştırmanın Kavramsal Modeli

Modelde görüldüğü üzere araştırmanın temel amacına yönelik bir hipotez geliştirilmiştir. Bu hipotez aşağıda verilmiştir.

Hipotez 1: Öğrencilerin dijital okuryazarlıklarının internet girişimcilik niyetleri üzerinde pozitif etkisi vardır.

\section{3. Çalışmanın Bulguları}

Bu bölümde çalışmanın örneklemine ilişkin bilgilere, verilerin analizine ve hipotez testine yer verilmiştir.

\subsection{1. Örnekleme İlişkin Bulgular}

Araştırmaya farklı bölümlerden öğrencilerin katılımı sağlanmış olup dağılımı; \%41,2'si İşletme, \%15,2'si İktisat, \%16,4'ü Uluslararası Ticaret, \%15,6'sı Uluslararası İlişkiler, \%11,6'sı ise Siyaset Bilimi ve Kamu Yönetimi bölümü öğrencisidir. \%31,8'i 1. sınıf, \%20,6'sı 2. sınıf, $\% 30,2$ 'si 3. sınıf, \%17,4'ü 4. sinıf öğrencisidir.

Araştırmaya katılan öğrencilerden girişimcilik eğitimi alanların oranı $\% 28,6$ olup, herhangi bir işletmede çalışanların oranı ise 59,4'tür.

Katılımcı öğrencilerin yaklaşık üçte ikisinin -(\%67,4'ünün) kendine ait bilgisayarı bulunmaktadır. Araştırmaya katılan öğrencilerin \%48'i 9 yıl ve üzeri, \%28,4'ü 6-8 yıl arası, \%15'i 3-5 yıl arası ve \%8,6'sı 0-2 yıl arası bir süre için bilgisayar kullanıcısıdır. Söz konusu öğrencilerden \%98,8'inin akıllı telefonu bulunmaktadır ve \%92,2'si sürekli bir internet bağlantısına sahiptir. Katılımcı öğrenciler internette günlük geçirdikleri zaman açısından değerlendirildiğinde \%43'ü 4-6 saat, \%30'u 1-3 saat, \%17,2'si 8-10 saat, \%4'ü 11-13 saat, \%3'ü 18 saat ve üzeri, \%2'si 1 saatten az, \%0,8'i ise 15-17 saat arası bir süreyi internette geçirmektedir. Söz konusu öğrencilerin \%74,2'sinin sosyal paylaşım-sohbet siteleri, $\% 10^{\prime}$ unun oyun-film siteleri, $\% 8,6$ 'sının haber-blog siteleri ve $\% 7,2^{\prime}$ sinin eğitim, ödev ve forum siteleri internette en sık ziyaret ettiği sitelerdir. Son olarak, sosyal bir ağa üye olanların oranı $\% 76,4^{\prime}$ tür.

\subsubsection{Verilerin Analizi}

Araştırmanın temel amacına yönelik oluşturulan hipotezin test edilmesinde Yapısal Eşitlik Modeli'nden-YEM (Structural Equation Modeling) yararlanılmıştır. YEM, ölçülen değişkenler arasındaki ilişkiyi gözlemleyerek anlamlı şekilde açıklayan ve teorik modelin 
test edilmesinde kullanılan etkili bir yöntemdir (Hoyle, 1995; 17). Çalışmada YEM analizinden önce SPSS-22 paket programı yardımıyla Keşifsel Faktör Analizi yapılmış olup bu analiz ile ölçeklerin orijinal ölçekteki boyutlarıyla uyumluluğu incelenmiştir. YEM analizi için AMOS 18.0 paket programından yararlanılmıştır.

\subsubsection{Keşifsel Faktör Analizi}

Çalışmada öncelikli olarak ölçeklerin güvenilirliğgi (reliability analysis) incelenmiştir. Güvenilirlik analizinde Cronbach Alpha değerinin kabul edilebilir sınır olan 0,70'in üzerinde olması (Nunnally, 1978; Coşkun vd., 2017: 133) şartı aranmıştır. Değişkenlerin faktör analizine uygunluğunu belirlemek için ise KMO değerinin 0,50'den yüksek olması ve aynı zamanda ve Chi-Square değerinin istatistiksel bakımdan anlamlı olması şartı (Çakır, 2014: 5) aranmıştır. Faktör yüklerini belirlerken maksimum olabilirlik (maximum likelihood) tahmin yöntemi ve literatürde sıklıkla kullanılan varimax rotasyonu (Coşkun vd., 2017: 284) kullanılmıştır. Her bir faktörde özdeğerin 1'den büyük olması (Güriş ve Astar, 2014: 376) ve faktör yüklerinin 0,50 ve üzeri olması (Hair vd., 2014: 108) ayrıca açıklanan varyansın \%50'den düşük olmaması (Habing, 2005: 4) aranan diğer şartlardır. Bu bağlamda Tablo 1 ve Tablo 2'de çalışmanın ölçeklerine ilişkin Cronbach Alpha $(\alpha)$ değerleri, faktör yükleri, her faktörün açıkladığı varyans (variance explaned/VE), özdeğerleri ve diğer bulgular yer almaktadir. 
Tablo 1. Dijital Okuryazarlık Ölçeğine İlişkin Keşifsel Faktör Analizi

\begin{tabular}{|c|c|c|c|c|c|}
\hline & Iffadeler & Faktör Yükü & Ort. & Std. Sap. & Ölçek Ort. \\
\hline \multirow{10}{*}{$\underset{\Xi}{\Xi}$} & $\begin{array}{l}\text { Öğrenme sürecinde bilgi ve iletişim teknolojilerini } \\
\text { kullanmak hoşuma gider. }\end{array}$ & 0,711 & 3,60 & 1,03 & \multirow{7}{*}{3,76} \\
\hline & $\begin{array}{l}\text { Bilgi ve iletişim teknolojilerini kullanarak daha iyi } \\
\text { öğrenirim. }\end{array}$ & 0,774 & 4,00 & 1,01 & \\
\hline & $\begin{array}{l}\text { Bilgi ve iletişim teknolojilerini kullanarak öğrenmek } \\
\text { daha ilgi çekicidir. }\end{array}$ & 0,759 & 3,98 & 1,00 & \\
\hline & $\begin{array}{l}\text { Bilgi ve iletişim teknolojilerini kullanarak öğrenmek } \\
\text { beni daha motive eder. }\end{array}$ & 0,777 & 3,50 & 1,02 & \\
\hline & $\begin{array}{l}\text { Öğrenme etkinliklerim için arkadaşlarımdan sıklıkla } \\
\text { İnternet aracılığıyla (Skype, Face ve Bloglar vb.) } \\
\text { yardım alırım. }\end{array}$ & 0,677 & 3,55 & 1,07 & \\
\hline & $\begin{array}{l}\text { Bilgi ve iletişim teknolojilerini kullanarak öğrenmek } \\
\text { öz-yönetimli ve bağımsız olmamı sağlar. }\end{array}$ & 0,689 & 3,87 & 0,98 & \\
\hline & $\begin{array}{l}\text { Karşılaştığım teknik problemleri nasıl çözeceğimi } \\
\text { bilirim. }\end{array}$ & 0,674 & 3,79 & 0,91 & \\
\hline & Özdeğer & 7,069 & & & \\
\hline & Açılanan Varyans & 24,441 & & & \\
\hline & Cronbach'alpha & 0,886 & & & \\
\hline \multirow{9}{*}{ |ֶ, } & $\begin{array}{l}\text { Yeni teknolojilerin kullanımını kolaylıkla } \\
\text { öğrenebilirim. }\end{array}$ & 0,772 & 4,10 & 1,06 & \multirow{6}{*}{3,87} \\
\hline & $\begin{array}{l}\text { Önemli olduğunu düşündüğüm yeni teknolojilere ayak } \\
\text { uydurabilirim. }\end{array}$ & 0,772 & 4,00 & 1,02 & \\
\hline & Birçok farklı teknoloji hakkında bilgim var. & 0,770 & 3,90 & 1,05 & \\
\hline & $\begin{array}{l}\text { Öğrenmede ve yeni şeyler oluşturmada (Sunumlar, } \\
\text { dijital hikâyeler, wikiler, bloglar vb.) bilgi ve iletişim } \\
\text { teknolojilerini kullanmak için gerekli olan teknik } \\
\text { becerilere sahibim. }\end{array}$ & 0,666 & 3,76 & 1,06 & \\
\hline & $\begin{array}{l}\text { İnternetten bilgi elde etmeye yönelik araştırma ve } \\
\text { değerlendirme becerilerime güvenirim. }\end{array}$ & 0,740 & 3,69 & 1,19 & \\
\hline & $\begin{array}{l}\text { Öğrenme sürecinde mobil teknolojilerin (Cep } \\
\text { telefonları, PDAs, Ipadler, akıllı telefonlar vb.) } \\
\text { kullanım potansiyeli yüksektir. }\end{array}$ & 0,802 & 3,79 & 1,09 & \\
\hline & Özdeğer & 1,891 & & & \\
\hline & Açılanan Varyans & 22,687 & & & \\
\hline & Cronbach'alpha & 0,890 & & & \\
\hline \multirow{5}{*}{ 离. } & $\begin{array}{l}\text { Öğretmenlerim ders anlatırken bilgi ve iletişim } \\
\text { teknolojilerini daha çok kullanmalıdır. }\end{array}$ & 0,777 & 3,84 & 1,10 & \multirow[b]{2}{*}{3,72} \\
\hline & $\begin{array}{l}\text { Bilgi ve iletişim teknolojileri proje çalışmalarında ve } \\
\text { diğer öğrenme etkinliklerinde arkadaşlarım ile daha iyi } \\
\text { işbirliği içinde çalışmamı sağlar. }\end{array}$ & 0,790 & 3,59 & 1,18 & \\
\hline & Özdeğger & 1,458 & & & \\
\hline & Açıklanan Varyans & 10,771 & & & \\
\hline & Cronbach'alpha & 0,753 & & & \\
\hline \multirow{5}{*}{ 조일. } & Bilgi ve iletişim teknolojileri becerilerim iyidir. & 0,789 & 3,53 & 1,17 & \multirow[b]{2}{*}{3,37} \\
\hline & $\begin{array}{l}\text { İnternet tabanlı aktivitelerle ilgili konuları (Örn; siber } \\
\text { güvenlik, eser hırsızlığı, araştırma konuları vb.) bilirim. }\end{array}$ & 0,902 & 3,21 & 1,26 & \\
\hline & Özdeğer & 1,032 & & & \\
\hline & Açılanan Varyans & 9,458 & & & \\
\hline & Cronbach'alpha & 0,728 & & & \\
\hline
\end{tabular}

Notlar: N=500; Cronbach'alpha=0,909; KMO=0,887; Bartlett Sph. Testi Chi-Square=4605,63; $<<0,001 ;$ Açılanan Toplam Varyans=\%67,356; Faktör Yükleri $\geq 0,50$. 
Tablo 1'de görüldüğü gibi Dijital Okuryazarlık ölçeğini oluşturan maddeler 4 boyuta ayrılmaktadır. Boyutlar literatüre uygun olarak Tutum, Teknik, Bilişsel ve Sosyal şeklinde adlandırılmıştır (Ng 2012, Hamutoğlu vd. 2017,Göldağ ve Kanat 2018, Yılmaz vd. 2019, Yaman 2019, Hamutoğlu vd. 2019). Her bir boyuta ve ölçeğin geneline ilişkin cronbach alpha güvenilirlik katsayısı 0,70'in üzerinde olup boyutların güvenilir olduğunu göstermektedir. Boyutların özdeğerleri 1'den büyüktür. Ölçek tarafından açıklanan toplam varyans değeri $\% 67,356^{\prime}$ dır. Ölçeği oluşturan her bir maddenin faktör yükü 0,5'ten büyüktür. Bu bağlamda ölçek güvenilirlik ve geçerlilik için gerekli tüm şartları sağlamaktadır.

Tablo 2. Girişimcilik Niyeti Ölçeğine İlişkin Keşifsel Faktör Analizi

\begin{tabular}{|c|c|c|c|c|}
\hline İfadeler & Faktör Yükü & Ort. & Std. Sap. & Ölçek Ort. \\
\hline Gelecekte internet üzerinden bir işe başlayacağım. & 0,902 & 2,90 & 1,08 & \multirow[t]{3}{*}{2,88} \\
\hline İnternet üzerinden bir iş başlatmak niyetindeyim. & 0,944 & 2,83 & 1,15 & \\
\hline Gelecekte internet üzerinden bir iş başlatmayı planlıyorum. & 0,941 & 2,91 & 1,17 & \\
\hline Özdeğer & 2,59 & & & \\
\hline Açıklanan Toplam Varyans & 86,35 & & & \\
\hline Cronbach'alpha & 0,921 & & & \\
\hline
\end{tabular}

Notlar: N=500; KMO=0,744; Bartlett Sph. Testi Chi-Square=1158,269; $\mathrm{p}<0,001$; Faktör Yükleri $-\geq 0,50$.

Tablo 2'de görüldüğü gibi Girişimcilik Niyeti ölçeğini oluşturan maddeler tek boyuta yüklenmektedir. Bu durum literatürle uyumludur (Wang ve Lin 2016, Bayrakdaroglu ve Bayrakdaroglu 2017). Ölçeğe ilişkin cronbach alpha güvenilirlik katsayısı 0,70'in üzerinde olup ölçeğin güvenilir olduğunu göstermektedir. Özdeğer 1'den büyüktür. Ölçek tarafından açılanan toplam varyans değeri \%86,35'tir. Ölçeği oluşturan her bir maddenin faktör yükü 0,5'ten büyüktür. Bu bağlamda ölçek güvenilirlik ve geçerlilik için gerekli tüm şartları sağlamaktadır.

\subsubsection{Doğrulayıcı Faktör Analizi}

Doğrulayıcı Faktör Analizi (DFA), yapısal geçerliliği KFA'da tespit edilen ölçeklerin araştırmanın yürütüldüğü örneklemde doğrulanıp doğrulanmadığını incelemektedir. Bu bağlamda DFA ile araştırma modelinin istatiksel olarak anlamlılığı ve uyumluluğunu belirten bazı değerler hesaplanmaktadır. Tablo 3 ve 4 'te DFA sonucu elde edilen değerler; ölçeklere yönelik yapı güvenilirliği $(\varrho \eta)^{1}$ ve açılanan varyans $(\mathrm{VE})^{2}{ }^{2}$, standardize regresyon yükleri, $\mathrm{t}$ değerleri ve bu değerlerin anlamlılıkları yer almaktadır.

${ }^{1} \rho_{\eta}$ : Yapı Güvenirliliği $=\left(\sum \text { standardize reg.ağr. }\right)^{2} /\left(\sum \text { standardize reg.ağr. }\right)^{2}+\sum$ ölçüm hatalar

${ }^{2}$ VE: Açıklanan Varyans $=\sum$ (standardize reg.ağr. $\left.{ }^{2}\right) / \sum$ (standardize reg.ağr. $\left.{ }^{2}\right)+\sum$ ölçüm hataları formülleri yardımıyla hesaplanmıştır (Fornell ve Larcker, 1981). 
Tablo 3. Dijital Okuryazarlık Ölçeğine İlişkin Doğrulayıcı Faktör Analizi

\begin{tabular}{|c|c|c|c|c|}
\hline & Madde & $\begin{array}{c}\text { Standardize } \\
\text { Regresyon Ağırlığı }\end{array}$ & $t$ & $P$ \\
\hline \multirow{7}{*}{$\begin{array}{c}\text { Tutum } \\
(\mathrm{o \eta}=0,879 ; \\
\text { V.E=0,514) }\end{array}$} & Karşılaştığım teknik problemleri nasıl çözeceğimi bilirim. & 0,695 & - & - \\
\hline & $\begin{array}{l}\text { Bilgi ve iletişim teknolojilerini kullanarak öğrenmek öz- } \\
\text { yönetimli ve bağımsız olmamı sağlar. }\end{array}$ & 0,734 & 14,981 & $<0,001$ \\
\hline & $\begin{array}{l}\text { Öğrenme etkinliklerim için arkadaşlarımdan sıklıkla } \\
\text { İnternet aracılığıyla (Skype, Face ve Bloglar vb.) yardım } \\
\text { alırım. }\end{array}$ & 0,603 & 12,370 & $<0,001$ \\
\hline & $\begin{array}{l}\text { Bilgi ve iletişim teknolojilerini kullanarak öğrenmek beni } \\
\text { daha motive eder. }\end{array}$ & 0,677 & 13,913 & $<0,001$ \\
\hline & $\begin{array}{l}\text { Bilgi ve iletişim teknolojilerini kullanarak öğrenmek daha } \\
\text { ilgi çekicidir. }\end{array}$ & 0,857 & 17,171 & $<0,001$ \\
\hline & $\begin{array}{l}\text { Bilgi ve iletişim teknolojilerini kullanarak daha iyi } \\
\text { öğrenirim. }\end{array}$ & 0,797 & 16,120 & $<0,001$ \\
\hline & $\begin{array}{l}\text { Öğrenme sürecinde Bilgi ve iletişim teknolojilerini } \\
\text { kullanmak hoşuma gider. }\end{array}$ & 0,621 & 12,709 & $<0,001$ \\
\hline \multirow{6}{*}{$\begin{array}{l}\text { Teknik } \\
\text { (@ך=0,878; } \\
\text { V.E }=0,551)\end{array}$} & $\begin{array}{l}\text { Öğrenme sürecinde mobil teknolojilerin (Cep telefonları, } \\
\text { PDAs, Ipadler, akıllı telefonlar vb.) kullanım potansiyeli } \\
\text { yüksektir. }\end{array}$ & 0,687 & - & - \\
\hline & $\begin{array}{l}\text { İnternetten bilgi elde etmeye yönelik araştırma ve } \\
\text { değerlendirme becerilerime güvenirim. }\end{array}$ & 0,556 & 15,887 & $<0,001$ \\
\hline & $\begin{array}{l}\text { Öğrenmede ve yeni şeyler oluşturmada (Sunumlar, } \\
\text { dijital hikâyeler, wikiler, bloglar vb.) bilgi ve iletişim } \\
\text { teknolojilerini kullanmak için gerekli olan teknik } \\
\text { becerilere sahibim. }\end{array}$ & 0,644 & 12,921 & $<0,001$ \\
\hline & Birçok farklı teknoloji hakkında bilgim var. & 0,805 & 15,891 & $<0,001$ \\
\hline & $\begin{array}{l}\text { Önemli olduğunu düşündüğüm yeni teknolojilere ayak } \\
\text { uydurabilirim. }\end{array}$ & 0,865 & 16,162 & $<0,001$ \\
\hline & Yeni teknolojilerin kullanımını kolaylıkla öğrenebilirim. & 0,848 & 15,875 & $<0,001$ \\
\hline \multirow{2}{*}{$\begin{array}{l}\text { Bilişsel } \\
(\varrho \eta=0,758 \\
\text { V.E }=0,613)\end{array}$} & $\begin{array}{l}\text { Bilgi ve iletişim teknolojileri proje çalışmalarında ve } \\
\text { diğer öğrenme etkinliklerinde arkadaşlarım ile daha iyi } \\
\text { işbirliği içinde çalışmamı sağlar. }\end{array}$ & 0,709 & - & - \\
\hline & $\begin{array}{l}\text { Öğretmenlerim ders anlatırken bilgi ve iletişim } \\
\text { teknolojilerini daha çok kullanmalıdır. }\end{array}$ & 0,851 & 12,427 & $<0,001$ \\
\hline \multirow{2}{*}{$\begin{array}{c}\text { Sosyal } \\
(\varrho \eta=0,763 \\
\text { V.E }=0,627)\end{array}$} & $\begin{array}{l}\text { İnternet tabanlı aktivitelerle ilgili konuları (Örn; siber } \\
\text { güvenlik, eser hırsızlığı, araştırma konuları vb.) bilirim. }\end{array}$ & 0,610 & - & - \\
\hline & Bilgi ve iletişim teknolojileri becerilerim iyidir. & 0,939 & 7,432 & $<0,001$ \\
\hline
\end{tabular}

Tablo 4. Girişimcilik Niyeti Ölçeğine İlişkin Doğrulayıcı Faktör Analizi

\begin{tabular}{|c|c|c|c|c|}
\hline & Madde & $\begin{array}{c}\text { Standardize } \\
\text { Regresyon Ağırlığı }\end{array}$ & $t$ & $P$ \\
\hline \multirow{3}{*}{$\begin{array}{c}\text { Girişimcilik } \\
\text { Niyeti } \\
\text { (@ๆ=0,922; } \\
\text { V.E }=0,799)\end{array}$} & Gelecekte internet üzerinden bir işe başlayacağım. & 0,821 & - & - \\
\hline & İnternet üzerinden bir iş başlatmak niyetindeyim. & 0,933 & 25,897 & $<0,001$ \\
\hline & $\begin{array}{l}\text { Gelecekte internet üzerinden bir iş başlatmayı } \\
\text { planlıyorum. }\end{array}$ & 0,923 & 25,693 & $<0,001$ \\
\hline
\end{tabular}

Doğrulayıcı Faktör Analizi'nde yapı güvenilirliğinin 0,70 ve açılanan varyansın 0,50 değerlerinden büyük olması şartı aranmaktadır (Hair vd., 1998: 612). Tablo 3 ve 4 incelendiğinde çalışmanın ölçeklerinin bu şartları sağladığı ve $\mathrm{t}$ değerlerinin istatiksel bakımdan anlamlı olduğu görülmektedir. Elde edilen bu bilgiler ışığında KFA ile elde edilen bulguların DFA ile doğrulandığ 1 tespit edilmiştir. 


\subsubsection{Yapısal Eşitlik Analizi Sonuçları}

Çalışmanın ölçeklerinin doğrulanmasından sonra hipotezin analizinde yapısal eşitlik modelinden yararlanılmıştır. Temel değişkenler arasındaki ilişkiler incelenmeden önce araştırma modelinin istatistiksel bakımdan anlamlı ve geçerli olup olmadığının tespit edilmesi gerekmektedir. $\mathrm{Bu}$ tespitin sağlanmasında uyum iyiliği indekslerinden faydalanılmaktadır. Tablo 5 'te bu indeksler ve indekslere ait iyi ve kabul edilebilir uyum ölçüleri ile modele ilişkin uyum ölçüleri yer almaktadır.

Tablo 5. Girişimcilik Niyeti Ölçeğine İlişkin Doğrulayıcı Faktör Analizi

\begin{tabular}{|l|c|c|c|}
\hline \multicolumn{1}{|c|}{ İndeksler } & İyi Uyum & Kabul Edilebilir Uyum & Önerilen Model \\
\hline$\chi^{2} / \mathrm{df}$ & $0<\chi^{2} / \mathrm{df}<3$ & $0<\chi^{2} / \mathrm{df}<5$ & 2,225 \\
\hline GFI & $0,95 \leq \mathrm{GFI} \leq 1$ & $0,90 \leq \mathrm{GFI} \leq 0,95$ & 0,984 \\
\hline AGFI & $0,90 \leq \mathrm{AGFI} \leq 1$ & $0,85 \leq \mathrm{AGFI} \leq 0,90$ & 0,966 \\
\hline NFI & $0,95 \leq \mathrm{NFI} \leq 1$ & $0,90 \leq \mathrm{NFI} \leq 0,95$ & 0,982 \\
\hline RFI & $0,90 \leq \mathrm{RFI} \leq 1$ & $0,85 \leq \mathrm{RFI} \leq 0,90$ & 0,971 \\
\hline IFI & $0,97 \leq \mathrm{IFI} \leq 1$ & $0,95 \leq \mathrm{IFI} \leq 0,97$ & 0,990 \\
\hline CFI & $0,97 \leq \mathrm{CFI} \leq 1$ & $0,95 \leq \mathrm{CFI} \leq 0,97$ & 0,990 \\
\hline RMSEA & $0 \leq \mathrm{RMSEA} \leq 0,05$ & $0,05 \leq \mathrm{RMSEA} \leq 0,10$ & 0,05 \\
\hline
\end{tabular}

Önerilen model ile veri arasındaki uyumun test edilmesinde kullanılan önemli değerlerden birisi $\chi^{2} /$ serbestlik derecesi değeridir (Marsh ve Hocevar, 1988). Önerilen modelde $\chi^{2} / \mathrm{df}$ değeri 2,225 olup, bu değerin iyi uyum sınırları içerisindedir.

- GFI (Goodness of Fit Index/Uyum Iyiliğ Indeksi); 0 ile 1 arasında değerler almaktadır. $\mathrm{Bu}$ indeksin 0,95 ile 1,00 aralığında değer alması iyi bir uyumun bulunduğunu göstermektedir (Shevlin ve Miles, 1998). Önerilen modele ilişkin GFI değeri 0,984 olup iyi uyum sınırları içerisindedir.

- AGFI (Adjusted Goodness of Fit Index/Düzeltilmis, Iyilik Uyum Indeksi) için 0,85-0,90 arasındaki değerler kabul edilebilir bir uyumun (Schermelleh-Engel vd., 2003: 43) göstergesi kabul edilmektedir. Önerilen model için elde edilen değer 0,966 olup iyi uyum sınırları içerisindedir.

- NFI'da (Normed Fit Index/Normlaştırılmış Uyum İndeksi) 0,95-1 aralığı iyi bir uyumun (Bozok, 2019: 40) göstergesi olup model için elde edilen değer bu aralıktadır.

- RFI (Relative Fit Index/Göreli Uyum İndeksi) değerinin 0,90'ın üzerinde bir değer alması beklenmektedir (Ayyıldız ve Cengiz, 2006). Model için elde edilen değer bu aralıkta yer alıp iyi uyum göstermektedir.

- IFI'da (Incremental Fit Index/Fazlalık Uyum İndeksi) değerinin genellikle 0,90'1n üzerinde olması beklenilmekte olup (Beauducel ve Wittmann, 2005: 59) model için elde edilen değer iyi uyum sınırları içerisindedir.

- CFI'de (Comperative Fit Index/Karşılaştırmalı Uyum İndeksi) 0,97-1 aralığı iyi bir uyumun (Schermelleh-Engel vd., 2003: 52; Meydan ve Şeşen, 2011:34) göstergesi olup model için elde edilen değer bu aralıktadır.

- RMSEA'da (Root Mean Square Error of Approximation/Tahmin Hatalarının Ortalamasının Karekökü) 0,05'ten küçük değerler iyi uyumun bulunduğunu 0,10 ve 
altındaki değerler kabul edilebilir uyumun bulunduğunu (Haşlaman, 2005) göstermekte olup model için elde edilen değer iyi uyum sınır değeridir.

$\mathrm{Bu}$ değerlendirmeler 1şığında önerilen modelin veri ile iyi uyum gösterdiği söylenilebilir. Dolayısıyla önerilen model istatiksel bakımdan anlamlı ve geçerli bir model olup hipotezlerin değerlendirilmesi mümkün hale gelmiştir.

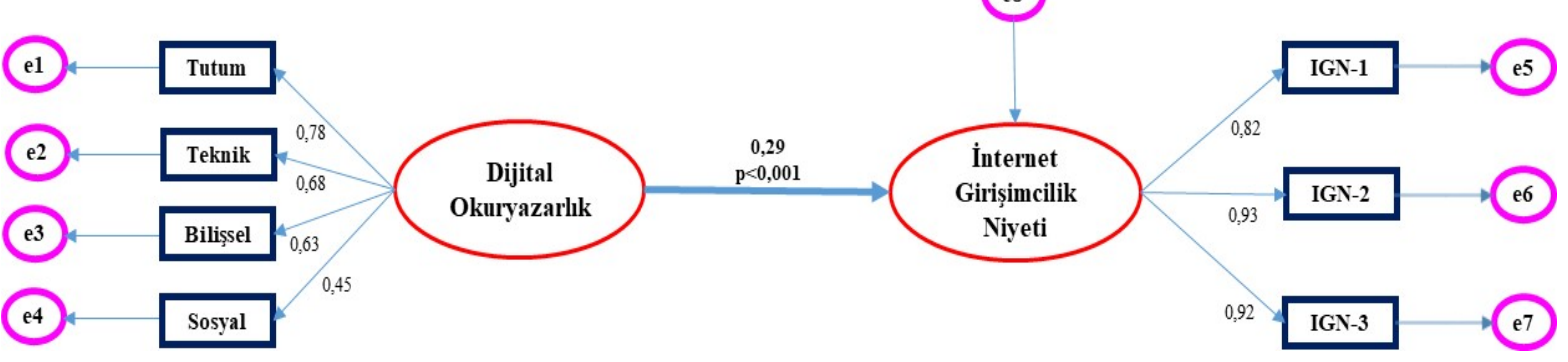

Şekil 2. Kavramsal Modele İlişkin YEM Analizi Sonuçları

Tablo 6. Modele İlişkin YEM Analizi Sonuçları

\begin{tabular}{|c|c|c|c|c|}
\hline \multirow{2}{*}{ Ölçek } & Madde & $\begin{array}{c}\text { Standart } \\
\text { Tahmin }\end{array}$ & Standart Hata & $\mathbf{t}^{*}$ \\
\hline \multirow{3}{*}{$\begin{array}{c}\text { Dijital } \\
\text { Okuryazarlık }\end{array}$} & Sosyal Boyut & 0,449 & - & - \\
\cline { 2 - 5 } & Bilişsel Boyut & 0,633 & 0,161 & 8,279 \\
\hline & Teknik Boyut & 0,682 & 0,149 & 8,203 \\
\hline \multirow{2}{*}{$\begin{array}{c}\text { Internet } \\
\text { Girişimcilik } \\
\text { Niyeti }\end{array}$} & $\begin{array}{c}\text { Gelecekte internet üzerinden bir işe } \\
\text { başlayacağım. }\end{array}$ & 0,822 & - & - \\
\cline { 2 - 5 } & $\begin{array}{c}\text { Internet üzerinden bir iş başlatmak } \\
\text { niyetindeyim. }\end{array}$ & 0,932 & 0,046 & 26,024 \\
\cline { 2 - 5 } & $\begin{array}{c}\text { Gelecekte internet üzerinden bir iş } \\
\text { başlatmayı planliyorum. }\end{array}$ & 0,923 & 0,047 & 25,808 \\
\hline
\end{tabular}

Not: * Bütün $t$ değerleri için $p<, 001$.

Çalışmanın temel amacına uygun olarak kurulan hipotezin değerlendirme sonuçları Tablo 7 'de yer almaktadir.

Tablo 7. Hipotezlere İlişkin Sonuçlar

\begin{tabular}{|c|c|c|c|c|c|}
\hline Hipotez & Std. Tahmin & Std. Hata & $\mathbf{t}$ & $\mathbf{p}$ & Sonuç \\
\hline $\begin{array}{l}\text { Öğrencilerin dijital okuryazarlıklarının internet } \\
\text { girişimcilik niyetleri üzerinde pozitif etkisi vardır. }\end{array}$ & 0,292 & 0,111 & 4,871 & $<0,001$ & $\begin{array}{l}\text { Kabul } \\
\text { Edildi }\end{array}$ \\
\hline
\end{tabular}

Şekil 2'de yer alan modele ilişkin YEM analiz sonuçları ve Tablo 6 ile 7 beraber değerlendirildiğinde çalışmanın öğrencilerin dijital okuryazarlıkları ile internet girişimcilik niyetleri değişkeni arasındaki ilişki katsayısının 0,292 ve $p<0,001$ olduğu görülmektedir. $\mathrm{Bu}$ bulgulara göre öğrencilerin dijital okuryazarlıklarının internet girişimcilik niyetleri üzerinde pozitif etkisi olduğunu ileri süren araştırma hipotezi kabul edilmiştir. Elde edilen bulgular literatürde daha önce yapılmış çalışmaların sonuçlarıyla benzerlik göstermektedir.

Örneğin Bayrakdaroglu ve Bayrakdaroglu (2017)'nun finansal okuryazarlık ve dijital okuryazarlığın internet girişimciliği üzerindeki etkisini belirlemek amaciyla gerçekleştirdikleri çalışmanın bulguları, hem finansal okuryazarlığın hem de dijital 
okuryazarlığın internet girişimciliği niyeti üzerinde önemli pozitif etkisi olduğunu göstermiştir. Buna ek olarak, dijital okuryazarlığın internet girişimciliği niyeti üzerindeki etkisi daha güçlü olmuştur. Bu bulguya dayanılarak, dijital bilginin daha önemli bir internet girişimciliği bileşeni olduğu sonucuna ulaşılmıştır. Chen ise 2013 ve 2014 yıllarındaki çalışmalarında, bilgisayar öz-yeterliliğinin internet girişimciliği niyeti üzerinde dolaylı bir etkisi olduğu sonucuna erişmiştir.

Öğrencilerin dijital okur okuryazarlıklarının internet girişimcilik niyetleri üzerinde pozitif etkisinin tespit edilmesinden sonra, dijital okuryazarlık düzeyi ile internet girişimcilik düzeyi arasındaki ilişkiyi irdelemek amacıyla öncelikle öğrencilerin dijital okuryazarlık ölçeğinden aldıkları puanlar, Güleş ve Çağlıyan (2003) tarafından uygulanan yöntem referans alınarak medyan kuralına göre düşük düzeyde ve yüksek düzeyde dijital okuryazarlık olmak üzere ikiye bölünmüştür. Daha sonra oluşan bu iki grubun internet girişimcilik niyetlerinde bir farklılık olup olmadığ 1 irdelenmiştir. Sonuçlar aşağıda Tablo 8 ' de görüldüğü gibidir.

Tablo 8. Öğrencilerin Dijital Okuryazarlık Düzeyine Göre İnternet Girişimcilik Niyetleri

\begin{tabular}{|c|c|c|c|c|c|c|}
\hline \multirow{2}{*}{} & \multicolumn{2}{|c|}{ Öğrencilerin Dijital Okuryazarlık Düzeyi } & \multicolumn{2}{c|}{$\begin{array}{c}\text { Mann-Whitney U } \\
\text { testi }\end{array}$} \\
\cline { 2 - 5 } & \multicolumn{2}{|c|}{ Düşük (n=262) } & Yüksek (n=238) & \multicolumn{2}{|c|}{ (n) } \\
\cline { 2 - 7 } & Ort. & Std. Sap. & Ort. & Std. Sap. & Z & p \\
\hline İnternet Girişimcilik Niyeti & 2,63 & 0,97 & 3,15 & 1,08 & $-5,193$ & $<0,001$ \\
\hline
\end{tabular}

Tablo 8'de görüldüğü gibi dijital okuryazarlık düzeyi yüksek olan öğrencilerin internet girişimcilik niyeti ölçeğinden aldıkları puanlar daha yüksek olup elde edilen sonuçlar istatistiksel bakımdan farklıdır. Bu durum, dijital okuryazarlığı yüksek olan öğrencilerin dijital okuryazarlığı düşük olan öğrencilere göre, internet girişimcilik niyetlerinin daha yüksek olduğu şeklinde değerlendirilebilir. Bu bağlamda üniversite eğitim sürecinde öğrencilere dijital okuryazarlığı artırıcı eğitimlerin verilmesinin, öğrencilerin internet girişimcilik niyetleri üzerinde pozitif etkisinin olacağı ileri sürülebilir.

\section{SONUÇ}

İnsanlık son yüz yılda oldukça önemli toplumsal dönüşümlere tanıklık etmektedir. 1900 yıllarda kırsal alandan kentlere doğru göçle başlayan bu değiş̧imler insanların kent yaşamına uyum sağlaması ile farklı boyutlara taşınmıştır. Bu dönüşüm üretimden tüketime, sağlıktan turizme hayatın birçok alanında farklılıkları ile hissedilmiş ve hissedilmeye devam etmektedir. Özellikle internetin bireysel kullanımı bu süreçteki en önemli dijital gelişmelerden birisi olarak karşımıza çıkmaktadır. Nitekim buhar enerjisinin üretim süreçlerinde kullanılmasıyla başlayan endüstriyel hayat nesnelerin interneti gibi kavramlarla Endüstri 4.0 olarak karşımıza çıkmakta ve bütün be değişimlerin bir sonucu olarak dijital hayata uyum sağlamış bir toplum yapısını tarifleyen Toplum 5.0 gibi kavramlar günümüzde sıkça duyulmaktadır. Bu bağlamda dijital okuryazarlık günümüzde hayatın tüm boyutları için oldukça önemli bir gerekliliktir.

Yukarıda tariflenen sürecin önemli bir parçası da yine dijital ortamda yürütülen ticari faaliyetler ve dolayısıyla girişimcilik uygulamalarıdır. Geleneksel yöntemlerle kıyaslandığında çok daha kolay bir şekilde hayata geçirilebilen dijital ticari faaliyetler yani 
internet üzerinden yürütülen girişimcilik faaliyetleri de toplumsal dönüşüm içerisinde kendisine yer bulmuş önemli uygulamalardır.

Bu bağlamda, bu çalışmada Selçuk Üniversitesi İktisadi ve İdari Bilimler Fakültesi'nde öğrenim görmekte olan öğrencilerin dijital okuryazarlıklarının internet girişimciliği niyetleri üzerindeki etkisi değerlendirilmiştir. Bu çalışma Doğrulayıcı Faktör Analizi ve Yapısal Eşitlik Modeli kullanarak gerçekleştirilmiş olup literatürdeki diğer “dijital okuryazarlığın internet girişimciliği niyeti üzerinde etkisini" ele alan çalışmalardan ayrıldığı ifade edilebilir. Bu şekilde aynı konuda farklı analiz yöntemleri ile elde edilen sonuçlarının karşılaştırılarak konunun uygulamadaki görünümüne ilişkin bilgi kümesinin artırılmasının literatüre katkısı olacağ1 düşünülmüştür.

Yapılan alan araştırması sonucunda dijital okuryazarlığın öğrencilerin internet üzerinden girişimcilik niyetleri üzerinde olumlu etkisi olduğu görülmüştür. Ayrıca öğrencilerin dijital okuryazarlıkları kendi içerisinde düşük ve yüksek düzeyde okuryazarlık olarak kategorize edildiğinde, dijital okuryazarlık düzeyleri yüksek olan öğrencilerin internet girişimcilik niyetlerinin de yüksek olduğu görülmüştür. Dolayısıyla eğitim hayatı boyunca öğrencilerin dijital okuryazarlığını geliştirici faaliyetlerin, derslerin ve/veya etkinliklerin artırılması, öğrencilerin internet üzerinden yürütecekleri ticari faaliyetleri yani girişimciliklerini olumlu etkileyecektir.

\section{KAYNAKÇA}

Akbaş, H. (2013). Grup Alışveriş Sitelerinin Sosyal Medyadaki Uygulamalarının Değerlendirilmesi. Denizli: Yüksek Lisans Tezi. Pamukkale Üniversitesi Sosyal Bilimler Enstitüsü,

Akış, M. L. (2017). Girişimcilik Seminerleri ve Türkiye İş Kurumu için Öneriler. Ankara: Çalışma ve Sosyal Güvenlik Bakanlığı Türkiye İş Kurumu Genel Müdürlüğü Uzmanlık Tezi.

Ayyıldız, H. ve Cengiz, E. (2006). “Pazarlama modellerinin testinde kullanılabilecek yapısal modeli (YEM) üzerine kavramsal bir inceleme", Süleyman Demirel Üniversitesi İ.I..B.F. Dergisi, 11(1), 63-84.

Bahcecik, Y. S., Akay, S. S. \& Akdemir, A. (2019). "A review of digital brand positioning strategies of the internet entrepreneurship in the context of virtual organizations: facebook, instagram and youtube samples", Procedia Computer Science, 158, 513-522.

Bawden, D. (2008). "Origins and concepts of digital literacy", Digital Literacies: Concepts, Policies and Practices, 30, 17-32.

Bayrakdaroglu, F. \& Bayrakdaroglu, A. (2017). “A comparative analysis regarding the effects of financial literacy and digital literacy on internet entrepreneurship intention", Girişimcilik ve Kalkınma Dergisi, 12(2), 27-38.

Beauducel, A., \& Wittmann, W. W. (2005). "Simulation study on fit indexes in CFA based on data with slightly distorted simple structure", Structural Equation Modeling, 12(1), 4175 . 
Bozok, G. (2019). İzmir İlinde Mesleki ve Teknik Eğitim Alan Lise Öğrencilerinin İşsizlik ve Kariyer Kaygılarının Yapısal Eşitlik Modeliyle İncelenmesi. İzmir: Yüksek Lisans Tezi, Dokuz Eylül Üniversitesi Sosyal Bilimler Enstitüsü.

Chen, L. (2013). "IT entrepreneurial intention among college students: an empirical study", Journal of Information Systems Education, 24(3), 233-243.

Chen, L. (2014). "Understanding IT entrepreneurial intention: an information systems view", Journal of Computer Information Systems, 55(1), 2-12.

Coşkun, R., Altunışık, R. ve Engin, Y. (2017). Sosyal Bilimlerde Araştırma Yöntemleri SPSS Uygulamalı (9 b.). Sakarya: Sakarya Yayıncılık.

Coşkun, Y. D., Cumaoğlu, G. K. ve Seçkin, H. (2013). “Bilgisayar öğretmen adaylarının bilişim alanıyla ilgili okuryazarlık kavramlarına yönelik görüşleri”, International Journal of Human Sciences, 10(1), 1259-1272.

Çakır, A. (2014, Aralık). Faktör Analizi. İstanbul: Doktora Tezi, İstanbul Ticaret Üniversitesi Sosyal Bilimler Enstitüsü.

Demir, K. ve Odabaşı, H. F. (2016). Dijital akıcılık kavramına eleştirel bir bakış. 4. Uluslararası Öğretim Teknolojileri ve Öğretmen Eğitimi Sempozyumu, 6-8 Ekim

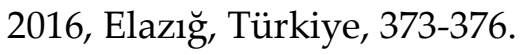

Dönmez, G. (2019). Lise Öğrencilerinin Bilgi Güvenliği Farkındalığı ile Dijital Okuryazarlığı Arasındaki İlişkinin İncelenmesi. Ankara: Yüksek Lisans Tezi. Hacettepe Üniversitesi Eğitim Bilimleri Enstitüsü,

Duran, E. ve Özen, N. E. (2018). “Türkçe derslerinde dijital okuryazarlı", Türkiye Ĕ̆gitim Dergisi, 3(2), 31-46.

Erdoğan, E., Çetinkaya, E. ve Kurutkan, M. N. (2006). Bilgi Çağı'nda girişimciliğin değişen boyutu: sanal girişimcilik. Uluslararası Girişimcilik Kongresi, 25-27 Mayıs 2006, Bişkek, Kırgızistan, 418-430.

Eshet-Alkalai, Y. \& Amichai-Hamburger, Y. (2004). "Experiments in digital literacy", CyberPsychology \& Behavior, 7(4), 421-429.

Eshet-Alkalai, Y. (2004). "Digital literacy: a conceptual framework for survival in the digital era", Journal of Multimedia and Hypermedia, 13(1), 93-106.

Fornell, C. \& Larcker, D. F. (1981). “Evaluating structural equation models with unobservable variables and measurement error", Journal of Marketing Research, 18(1), 39-50.

Gökgül, M. (2014). Türkiye'de Elektronik Ticaret ve İşletmelere, Tüketicilere Sağladığ1 Avantajlar, Dezavantajlar. İstanbul: Yüksek Lisans Tezi. İstanbul Kültür Üniversitesi Sosyal Bilimler Enstitüsü,

Göldağ, B. ve Kanat, S. (2018). “Güzel sanatlar eğitimi alan öğrencilerin dijital okuryazarlık durumlar1", The Journal of Academic Social Sciences Studies, 70, 77-92.

Guthrie, C. (2014). "The digital factory: a hands-on learning project in digital entrepreneurship", Journal of Entrepreneurship Education, 17(1), 115-133. 
Güleş, H. K. ve Çağlıyan, V. (2003). “İleri imalat teknolojileri kullanımının işletme performansına etkileri: küçük ve orta ölçekli sanayi işletmelerinde bir uygulama", Selçuk Üniversitesi İ.I.B.F. Ekonomik Araştırmalar Dergisi, Cilt:1, Sayı:5, 63-85.

Güriş, S. ve Astar, M. (2014). Bilimsel Araştırmalarda SPSS ile İstatistik. İstanbul: D.R Yayınevi.

Habing, B. (2005). Exploratory Factor Analysis. University of South Carolina.

Hair, J., Andreson, R., Tahtam, R., \& Black, C. (1998). Multivariate Data Analysis. New Jersey: Prentice-Hall International Inc.

Hair, J., Black, W. C., Babin, B. J., \& Anderson, R. E. (2014). Multivariate Data Analysis. Harlow: Pearson.

Hamutoğlu, N. B., Canan Güngören, Ö., Kaya Uyanık, G. ve Gür Erdoğan, D. (2017). “Dijital okuryazarlık ölçeği: Türkçe'ye uyarlama çalışması”, Ege Eğitim Dergisi, 1(18), 408- 429.

Hamutoğlu, N. B., Savaşçı, M. \& Sezen-Gültekin, G. (2019). “Digital literacy skills and attitudes towards e-learning", Journal of Education and Future, 16, 93-107.

Haşlaman, T. (2005). Programlama Dersi ile İlgili Özdüzenleyici Öğrenme Stratejileri ile Başarı Arasındaki İlişkilerin İncelenmesi: Bir Yapısal Eşitlik Modeli. Ankara: Yüksek Lisans Tezi, Hacettepe Üniversitesi Fen Bilimleri Enstitüsü.

Hejazinia, R. (2015). “The impact of IT-based entrepreneurship education on entrepreneurial intention", International Journal of Management, Accounting and Economics, 2(3), 243-253.

Hoyle, R. (1995). Structural Equation Modeling Concepts, Issues, and Applications. California: SAGE Publications.

İnce, E. ve Altın, E. (2018). Y ve M kuşaklarının internet girişimciliği niyetlerinin ölçülmesi: Iğdır Üniversitesi örneği. Iğdır 1. Uluslararası Multidisipliner Çalışmalar Kongresi, 68 Kasım 2018, Iğdır, Türkiye.

Kabakç1-Yurdakul, I., Dönmez, O., Yaman, F. ve Odabaşı, H. F. (2013). “Dijital ebeveynlik ve değişen roller", Gaziantep University Journal of Social Sciences, 12(4), 883-896.

Karabacak, G. \& Genç, M. (2019). The use of blogs as an example of internet entrepreneurship: Turkish travel blogs. Procedia Computer Science, 158, 869-876.

Karabacak, Z. İ. ve Sezgin, A. A. (2019). “Türkiye'de dijital dönüşüm ve dijital okuryazarlık”, Türk İdare Dergisi, 488, 319-343.

Kurt, A. A., Dönmez, F. İ., Ersoy, M., Dindar, M., Misırlı, Ö. ve Akçay, T. (2013). “Teknoloji 1şığında okuryazarlıklar", Ĕ̆itim Teknolojileri Araştırmaları Dergisi, 4(2).

Kuvat, Ö. (2019). “Bilişim sektöründe girişimcilik, Balıkesir üniversitesi bilgisayar mühendisliği öğrencilerinin girişimcilik eğilim ve niyetleri üzerine bir araştırma", Yönetim ve Ekonomi, 26(1), 295-308.

Lankshear, C. \& Knobel, M. (2015). “Digital literacy and digital literacies: policy, pedagogy and research considerations for education", Nordic Journal of Digital Literacy, 9(4), 8-20. 
Lin, X. (2015). A study on internet entrepreneurship intention of Chinese University students under demography's view. International Conference on Social Science, Education Management and Sports Education (SSEMSE 2015), April 10-11 2015, Beijing, China, 867-870.

Liñán, F. \& Chen, Y. (2009). "Development and cross-cultural application of a specific instrument to measure entrepreneurial intentions", Entrepreneurship: Theory and Practice, 33(3), 593-617.

Maden, S., Maden, A. ve Banaz, E. (2018). “Ortaokul 5. sınıf Türkçe ders kitaplarının dijital okuryazarlık bağlamında değerlendirilmesi”, Uluslararası Sosyal Araştırmalar Dergisi, 11(5), 685-698.

Malhotra, N. K. (2004). Marketing Research an Applied Orientation. New Jersey: Prentice Hall.

Marsh, H. W., \& Hocevar, D. (1988). "A new, more powerful approach to multitraitmultimethod analyses: application of second-order confirmatory factor analysis", Journal of Applied Psychology, 73(1), 107.

Maxwell, E. C., \& Maxwell, E. M. (2014). “Gender differences in digital literacy among undergraduate students of faculty of education, Kogi State University: implications for e-resources \& library use", Advances in Social Sciences Research Journal, 1(7), 96-108.

Meydan, C. ve Şeşen, H. (2011). Yapısal Eşitlik Modellemesi AMOS Uygulamaları. Ankara: Detay Yayıncilık.

Meyers, E. M., Erickson, I., \& Small, R. V. (2013). “Digital literacy and informal learning environments: an introduction", Journal Learning, Media and Technology, 38(4), 355-367.

Millman C., Li, Z. \& Matlay, H. \& Wong, W. (2010). “Entrepreneurship education and students' internet entrepreneurship intentions: evidence from Chinese HEIs", Journal of Small Business and Enterprise Development, 17(4), 569-590.

Milton, M. \& Vozzo, L. (2013). “Digital literacy and digital pedagogies for teaching literacy: pre-service teachers' experience on teaching rounds", Journal of Literacy and Technology, 14(1), 72-97.

Miynat, M. ve Özcan, P. M. (2016). Türkiye'de e-girişimcilik ve vergilendirilmesi. 7. Uluslararası Girişimcilik Kongresi, 12-14 May 2016, Bişkek, Kırgızistan, 506-520.

Nawaz, A. \& Kundi, G. M. (2010). "Digital literacy: an analysis of the contemporary paradigms", International Journal of Science and Technology Education Research, 1(2), 1929.

$\mathrm{Ng}$, W. (2012). "Can we teach digital natives digital literacy?", Computers \& Education, 59, 1065-1078.

Nunnally, J. (1978). Psychometric Theory. New York: McGraw-Hill.

Ocak, G. ve Karakuş, G. (2019). “Öğretmen adaylarının dijital okur-yazarlık öz-yeterliliği ölçek geliştirme çalışması”, Kastamonu Education Journal, 26(5), 1427-1436. 
Öz, S., Dindarik, N. ve Duman, F. (2019). "Schumpeteryan girişimcilik ve 21. yüzyıl girişimcilik yaklaşımları: y kuşağı girişimcileri üzerine nitel bir araştırma", Uluslararası Toplum Araştırmaları Dergisi, 13(19), 1056-1091.

Özbek, A., Esmer, Y. \& Şaylan, O. (2018). A model proposal for new product development in Turkish garment sector in the context of e-entrepreneurship. ICONSR 2018-1th International Conference on Social Science Research, 5-9 September 2018, Prizren, Kosovo, 10-17.

Sakallı, H. (2015). Sınıf Öğretmeni Adaylarının Dijital Vatandaşlık Düzeyleri ile Siber Zorbalık Eğilimleri Arasındaki İlişkinin İncelenmesi. Aydın: Yüksek Lisans Tezi, Adnan Menderes Üniversitesi, Sosyal Bilimler Enstitüsü Aydın.

Sarıkaya, B. (2019). “Türkçe öğretmeni adaylarının dijital okuryazarlık durumlarının çeşitli değişkenler açısından değerlendirilmesi", Uluslararası Sosyal Araştırmalar Dergisi, 12(62), 1098-1107.

Schermelleh-Engel, K., Moosbrugger, H., \& Müller, H. (2003). “Evaluating the fit of structural equation models: Tests of significance and descriptive goodness-of-fit measures", Methods of Psychological Research, 8(2), 23-74.

Shevlin, M., \& Miles, J. (1998). "Effects of sample size, model specification and factor loadings on the GFI in confirmatory factor analysis", Personality and Individual Differences, 25, 85-90.

Stalkina, L. \& Steiner, G. (2020). “Digital entrepreneurship and its role in innovation systems: a systematic literature review as a basis for future research avenues for sustainable transitions", Sustainability 2020, 12, 2764-2790.

Techataweewan, W. \& Prasertsin, U. (2018). “Development of digital literacy indicators for Thai undergraduate students using mixed method research", Kasetsart Journal of Social Sciences, 39, 215-221.

Üstündağ, M. T., Güneş, E. \& Bahçivan, E. (2017). “Turkish adaptation of digital literacy scale and investigating pre-service science teachers' digital literacy", Journal of Education and Future, 12, 19-29.

Vural, M. ve Çavuş, Ş. (2017). “Elektronik girişimcilik ve Kırgızistan'da uygulanma olanakları", Akademik Bakış Dergisi, 59, 50-64.

Wang, Y. M. \& Lin, Y. S. (2016). “Determinants of internet entrepreneurship intentions among business school students", International Journal of Information and Education Technology, 6(10), 754-758.

Yaman, C. (2019). Sosyal Bilgiler Öğretmen Adaylarının Dijital Okuryazarlık Düzeylerinin İncelenmesi (Niğde Ömer Halisdemir Üniversitesi Örneği). Niğde: Yüksek Lisans Tezi, Niğde Ömer Halisdemir Üniversitesi Eğitim Bilimleri Enstitüsü.

Yaşar, Ç. (2019). BÖTE Öğretmen Adaylarının Kariyer Eğilimlerinin, Sosyal Medyaya İlişkin Görüşlerinin ve Dijital Okuryazarlık Beceri Düzeylerinin İncelenmesi. Balıkesir: Yüksek Lisans Tezi, Balıkesir Üniversitesi Fen Bilimleri Enstitüsü. 
Yazıcıŏlu, Y. ve Erdoğan, S. (2004). SPSS Uygulamalı Bilimsel Araştırma Yöntemleri. Ankara: Detay Yayıncılık.

Yelkikalan, N, Akatay, A. ve Altın, E. (2010). “Yeni girişimcilik modeli ve yeni nesil girişimci profili: internet girişimciliği ve $\mathrm{y}, \mathrm{m}, \mathrm{z}$ kuşağı girişimci", S.Ü. İ.I.B.F. Sosyal Ekonomik Araştırmalar Dergisi, 10(20), 489-506.

Yıldırım, O. ve Başer, E. (2016). "İnternetin girişimciliği kapsamında değişen enformasyon siteleri üzerine bir değerlendirme", Global Media Journal TR Edition, 6(12), 172-200.

Yılmaz, A., Kaya, M. Akca, N. ve Sönmez, S. (2019). Sağlık bilimleri fakültesi öğrencilerinin dijital okuryazarlık düzeylerinin incelenmesi. 3. Uluslararası 13. Ulusal Sağlık ve Hastane İdaresi Kongresi, 10-13 Ekim 2019, Sakarya, Türkiye, 287-297. 